\title{
Causes of interruption of bevacizumab therapy in age-related macular degeneration
}

\author{
Causas de interrupção do tratamento com bevacizumab em \\ degeneração macular relacionada à idade
}

\author{
Renata Portella Nunes ${ }^{1}$ \\ Mário Junqueira Nóbrega ${ }^{2}$ \\ Fernando José De Novelli ${ }^{3}$ \\ Samuel Ângelo Coral ${ }^{4}$ \\ Thais Bacha Berti ${ }^{5}$ \\ Marina Maria Drumm Missen ${ }^{6}$ \\ Marina Canuto Correa ${ }^{7}$
}

Work carried out at Retina and Vitreous Department Hospital de Olhos "Sadalla Amin Ghanem" - Joinville (SC) - Brazil.

${ }^{1}$ Hospital Regional de São José "Dr. Homero de Miranda Gomes”, São José (SC) - Brazil.

${ }^{2}$ Hospital de Olhos "Sadalla Amin Ghanem", Joinville (SC) - Brazil. Joinville Regional University - Joinville (SC) - Brazil.

Hospital de Olhos "Sadalla Amin Ghanem" - Joinville (SC) - Brazil.

${ }^{4}$ Hospital de Olhos "Sadalla Amin Ghanem" - Joinville (SC) - Brazil.

${ }^{5}$ Hospital de Olhos "Sadalla Amin Ghanem" - Joinville (SC) - Brazil.

${ }^{6}$ Joinville Regional University - Joinville (SC) - Brazil. 7 Joinville Regional University - Joinville (SC) - Brazil. Correspondence address: Renata Portella Nunes. Av. Ipê Amarelo, 37 - Florianópolis (SC) CEP 88062-298 E-mail: reportella@hotmail.com

Recebido para publicação em 28.10.2009 Aprovação em 19.02.2010

Nota Editorial: Depois de concluída a análise do artigo sob sigilo editorial e com a anuência do Dr. Luiz Carlos Molinari Gomes sobre a divulgação de seu nome como revisor, agradecemos sua participação neste processo.

\begin{tabular}{|l|}
\hline ABSTRACT \\
\hline Purpose: To evaluate the rate and the causes of interruption of bevaci- \\
zumab intravitreal therapy in patients with exudative age-related macular \\
degeneration (AMD) in a referential eye-care center in Joinville, southern \\
Brazil. Methods: Retrospective, non-comparative, consecutive case series. \\
Cases included all patients with exudative age-related macular degene- \\
ration who were treated with one or more bevacizumab intravitreal \\
injections at Sadalla Amin Ghanem Eye Hospital between January, 2006 \\
and January, 2008. Data were obtained from patients' medical records and \\
telephone interviews. Discontinuity criterion was the absence of patient \\
follow-up after a minimum of 3 months from the last ophthalmic examina- \\
tion. Results: Eighty-two patients were treated. Among them, 24 (29.3\%) \\
interrupted follow-up inadvertently. The mean age was 75.2 years old \\
(range 65-89 yo). Mean number of bevacizumab intravitreal injections \\
was 2.0 (range 1-6). Nineteen patients answered to telephone question- \\
naires. The main alleged causes of discontinuity of therapy were unexpec- \\
ted poor visual results ( 8 cases, $42.1 \%$ ), lack of information about follow- \\
up visits (5 cases, $26.3 \%$ ) and comorbidities (3 cases, $15.8 \%$ ). Conclusions: \\
A high number of patients interrupted follow-up after beginning bevaci- \\
zumab therapy. Many of them related avoidable causes for discontinuity \\
of treatment. Efforts must be done to improve education of age-related \\
macular degeneration patients, especially in relation to functional outco- \\
mes and prolonged follow-up care.
\end{tabular}

Keywords: Macular degeneration; Choroidal neovascularization; Vascular endothelial growth factor A; Angiogenesis inhibitors/therapeutic use; Bevacizumab/therapeutic use

\section{INTRODUCTION}

Age-related macular degeneration (AMD) is the leading cause of irreversible blindness among people over 55 years old in western countries. The occurrence of AMD increases with age, so it is expected to become more prevalent in developed countries as life expectancy continues to increase ${ }^{(1-5)}$.

Although exudative (or neovascular) AMD is less common than dry AMD, occurring in approximately 10 to $20 \%$ of the patients, it is usually responsible for most severe cases of vision $\operatorname{loss} \mathrm{s}^{(1,6-7)}$.

Choroidal neovascularization ( $\mathrm{CNV})$, the abnormal growth of new blood vessels from choriocapillaris into the subretinal space, is the hallmark of exudative AMD and its treatment has been challenging researchers and specialists during the last decades. In the 1990's, Macular Photocoagulation Study showed that hot laser treatment could be beneficial for well-defined lesions (classic neovascular membranes) ${ }^{(8)}$. Nevertheless, as the same laser 
energy delivered to destroy subretinal new vessels also damages neurosensory retina, there is a permanent vision loss where the shots are applied. So, nowadays, laser photocoagulation is restricted to treatment of extrafoveal choroidal new vessels.

In 2000, photodynamic therapy (PDT) was approved for the treatment of some subtypes of CNV. It combines the use of an intravenous injected photosensitizing drug (verteporfin) with low-intensity laser light and damages choroidal new vessels through a photochemical reaction. Thus, PDT selectively ablates lesions while minimizing injury to adjacent structures. It has also been combined with intravitreal triamcinolone to permit more favorable results. Generally, results of PDT for subfoveal neovascular membranes have been limited to stabilization of the process and the visual acuity ${ }^{(1-2,5-6)}$.

Vascular endothelial growth factor (VEGF) has been proved to be important in the development of abnormal vessels and on the increase of its permeability in many pathological conditions. VEGF is produced in response to low oxygen tension in the affected tissues. Studies have identified the isoform VEGF-A as one of the most important that determines the vascular changes. With greater understanding of the role of VEGF in the pathogenesis of neovascular AMD, drugs inhibiting the bioactivity of VEGF have been developed and introduced in the clinical setting. Nowadays, intravitreal antiVEGF represents a new paradigm in exudative AMD therapy due to its better outcomes ${ }^{(1-4,7,9-10)}$.

Bevacizumab (Avastin ${ }^{\circledR}$ ) is a recombinant humanized fulllength anti-VEGF derived from a murine antibody with a molecular weight of $148 \mathrm{kD}$. It was designed for endovenous administration and was approved for the treatment of metastatic colorectal cancer in 2004. It has also been frequently and successfully used as an off-label intravitreal treatment of neovascular AMD since 2006. Bevacizumab has a longer halflife than ranibizumab, the actual most efficient anti-VEGF approved by ANVISA for AMD treatment, and is supposed to require less frequent dosing ${ }^{(1-7,10-12)}$.

Despite the better visual results achieved with bevacizumab therapy for choroidal neovascularization, its benefits seem to be temporary. Thereby, repeated injections are needed to reach and maintain the best visual acuity ${ }^{(6,13)}$. Many patients give up antiangiogenic therapy at different times and have worse functional outcomes, regardless of the usual improvement observed after the beginning of the treatment.

The purpose of this study is to evaluate the rate and the causes of interruption of bevacizumab intravitreal therapy in patients with exudative AMD in a referential eye-care center in Joinville, state of Santa Catarina, southern Brazil.

\section{METHODS}

This is a retrospective, non-comparative, consecutive case series. Cases included all patients with exudative AMD who were treated with one or more bevacizumab intravitreal injections at Sadalla Amin Ghanem Eye Hospital between
January 2006 and January 2008. Previously treated eyes with hot laser, PDT or intravitreal triamcinolone were excluded. Demographics, $\log$ MAR best-corrected visual acuity testing (BCVA) and number of injections were obtained from patients' medical records.

The causes of cessation of therapy were obtained through telephone interviews. The criterion of interruption of treatment was the absence of patient follow-up after a minimum of 3 months from the last ophthalmic examination.

\section{RESULTS}

Eighty-two patients were treated. Among them, 24 (29.3\%) interrupted follow-up inadvertently. Thirteen patients were men (54.2\%) and the mean age was 75.2 years old (range 65-89 yo). The treatment was unilateral in 19 patients (79.2\%). Mean logMAR BCVA varied from 1.02 (SD 0.61) before treatment to 0.98 (SD 0.58) at the last ophthalmic evaluation $(p>0.05)$.

Fourteen patients (58.3\%) who interrupted follow-up had a BCVA improvement after initiating therapy. Mean number of bevacizumab intravitreal injections was 2.0 (range 1-6). Nineteen patients (79.2\%) answered to telephone questionnaires. The alleged causes of discontinuity of therapy were unexpected poor visual results ( 8 cases, $42.1 \%$ ), lack of information about follow-up visits ( 5 cases, $26.3 \%$ ), comorbidities such as malignancy, Alzheimer's disease and cerebral vascular disease ( 3 cases, 15.8\%), difficulties in booking new appointments (2 cases, $10.5 \%$ ) and travelling problems (1 case, 5.3\%) (Figure 1). Among the 8 cases described as having unexpected poor visual results, there were included 5 patients $(26.3 \%)$ who related questionable cost-benefit relation.

\section{DISCUSSION}

Pharmacologic therapy with angiogenesis inhibitors have modified significantly the outcomes in many retinal vascular diseases, including exudative age-related macular degeneration $^{(14-18)}$.

Since 2006, the use of off-label intravitreal therapy with bevacizumab, an anti-VEGF humanized monoclonal antibody, has greatly expanded throughout the world. It combines effectiveness, safety and cost facilities ${ }^{(7,9,12,17-18)}$.

Despite the favorable results of bevacizumab in a significant number of patients with exudative AMD, its small intravitreal half-life usually limits its effect. And, as AMD is a longstanding disease with frequent choroidal neovascularization recurrences, the patients often need several intravitreal injections, during months or years, to improve and maintain their best visual acuity.

In this study, among 82 patients treated with bevacizumab for neovascular AMD, an unexpected high number of patients gave up therapy at different moments (29.3\%). And, most interestingly, many of them had stable or slightly improved BCVA before interruption of follow-up visits. 


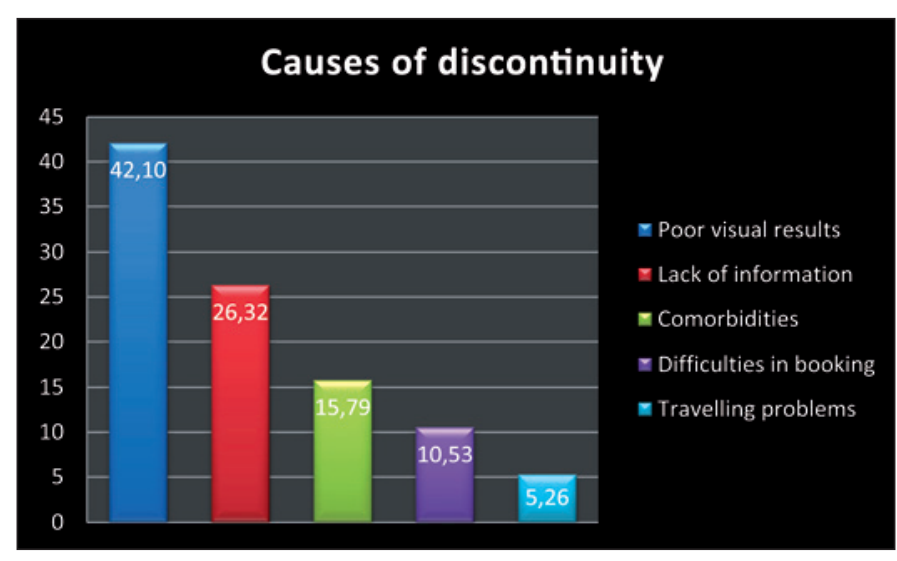

Figure 1 - Causes of interruption of bevacizumab therapy in exudative AMD at Sadalla Amin Ghanem Eye Hospital, Joinville (SC), between January 2006 and January 2008

Although this study has some drawbacks, such as a retrospective design, a limited number of patients and time of follow-up and an acquisition of data related to discontinuity of treatment through telephone interviews, it was observed that the majority of alleged causes were preventable.

One factor that may avoid this unfavorable event is the correct education of the patients and their families about exudative AMD before initiating therapy. It is mandatory to explain adequately about the usual progression of the disease if left untreated, the importance of therapy and the necessity of frequent intravitreal injections and follow-up visits, at different intervals, to permit better results and visual stability.

Possibly, in the studied group of patients who gave up follow-up, a more satisfactory previous explanation could permit better adherence to treatment and, consequently, visual benefits. Nonetheless, it is necessary to emphasize that many patients come from distant places and difficulties in transportation and housing may interfere with the optimal regimen of ophthalmological assistance.

In addition, it is known that patients with AMD are frequently frustrated and depressed due to their inability to perform tasks that involve a good central vision and the lack of hope of significant functional improvements. An even greater frustration after a therapy that was supposed to permit better visual results might be an important cause of discontinuity of treatment.

Concerning the vascular cerebral disease that one patient alleged as the cause of cessation of bevacizumab therapy, the medical records showed that he had an earlier diagnosis of a vascular cerebral malformation and it did not have relation to the ocular treatment; the interruption of ophthalmologic follow-up occurred 1 year and 8 months after the intravitreal injection.

\section{CONCLUSIONS}

A high number of patients interrupted follow-up after beginning bevacizumab therapy for exudative AMD. Many of them related avoidable causes for discontinuity of treatment. Efforts must be done to improve information to AMD patients, especially in relation to functional outcomes and prolonged follow-up care.

\section{RESUMO}

Objetivos: Avaliar as causas de interrupção do tratamento com bevacizumab intravítreo nos pacientes portadores da forma exsudativa de degeneração macular relacionada à idade acompanhados no Hospital de Olhos "Sadalla Amin Ghanem", em Joinville (SC). Métodos: Série de casos retrospectiva, consecutiva e não-comparativa. Incluíram-se os pacientes com degeneração macular relacionada à idade exsudativa tratados com uma ou mais injeções intravítreas de bevacizumab entre janeiro de 2006 e janeiro de 2008. Os dados foram obtidos dos prontuários dos pacientes e de entrevistas telefônicas. O critério de descontinuação foi a ausência do paciente à consulta após o mínimo de três meses a partir da última avaliação oftalmológica. Resultados: Dentre os 82 pacientes tratados, 24 interromperam o tratamento inadvertidamente $(29,3 \%)$. A média de idade foi 75,2 anos (65-89 anos). O número médio de injeções intravítreas de bevacizumab foi 2,0 (variação 1-6). Dezenove pacientes responderam aos questionários através de contato telefônico. As principais causas de interrupção do tratamento foram o resultado visual abaixo do esperado ( 8 casos, 42,1\%), a falta de informação sobre o controle clínico oftalmológico ( 5 casos, 26,3\%) e comorbidades sistêmicas (3 casos, 15,8\%). Conclusão: Um elevado número de pacientes interrompeu o acompanhamento após início de terapia intravítrea com bevacizumab. Muitos deles referiram causas evitáveis de descontinuação do tratamento. Esforços devem ser feitos para propiciar informação mais adequada aos portadores de degeneração macular relacionada à idade exsudativa em vigência deste tratamento, especialmente com relação aos resultados funcionais e acompanhamento prolongado.

Descritores: Degeneração macular; Membrana neovascular sub-retiniana; Fator A de crescimento endotelial vascular; Inibidores da angiogênese/uso terapêutico; Bevacizumab/uso terapêutico

\section{REFERENCES}

1. Lazic R, Gabric N. Intravitreally administered bevacizumab (Avastin) in minimally classic and occult choroidal neovascularization secondary to age-related macular degeneration. Graefes Arch Clin Exp Ophthalmol. 2007;245(1):68-73

2. Aisenbrey S, Ziemssen F, Völker M, Gelisken F, Szurman P, Jaissle G, et al. Intravitreal bevacizumab (Avastin) for occult choroidal neovascularization in age-related macular degeneration. Graefes Arch Clin Exp Ophthalmol. 2007; 245(7):941-8.

3. Ni Z, Hui P. Emerging pharmacologic therapies for wet age-related macular degeneration. Ophthalmologica. 2009;223(6):401-10. Review.

4. Kourlas H, Abrams P. Ranibizumab for the treatment of neovascular age-related macular degeneration: a review. Clin Ther. 2007;29(9):1850-61. 
5. Bressler NM; Treatment of Age-Related Macular Degeneration with Photodynamic Therapy (TAP) Study Group. Photodynamic therapy of subfoveal choroidal neovascularization in age-related macular degeneration with verteporfin: twoyear results of 2 randomized clinical trials - tap report 2. Arch Ophthalmol. 2001;119(2):198-207. Comment in: Arch Ophthalmol. 2005;123(9):1283-5.

6. Yip PP, Woo CF, Tang HH, Ho CK. Triple therapy for neovascular age-related macular degeneration using single-session photodynamic therapy combined with intravitreal bevacizumab and triamcinolone. Br J Ophthalmol. 2009; 93(6):754-8

7. Wu L, Fernando Arevalo J, Maia M, Berrocal MH, Sanchez J, Evans T; PanAmerican Collaborative Retina Study Group (PACORES). Comparing outcomes in patients with subfoveal choroidal neovascularization secondary to age-related macular degeneration treated with two different doses of primary intravitreal bevacizumab: results of the Pan-American Collaborative Retina Study Group (PACORES) at the 12-month follow-up. Jpn J Ophthalmol. 2009; 53(2):125-30.

8. Persistent and recurrent neovascularization after krypton laser photocoagulation for neovascular lesions of age-related macular degeneration. Macular Photocoagulation Study Group. Arch Ophthalmol. 1990;108(6):825-31.

9. Avery RL, Pieramici DJ, Rabena MD, Castellarin AA, Nasir MA, Giust MJ. Intravitreal bevacizumab (Avastin) for neovascular age-related macular degeneration. Ophthalmology. 2006;113(3):363-72.e5. Comment in: Ophthalmology. 2007;114(2):400; author reply 400-1.

10. Conrad PW, Zacks DN, Johnson MW. Intravitreal bevacizumab has initial clinical benefit lasting eight weeks in eyes with neovascular age-related macular degeneration. Clin Ophthalmol. 2008;2(4):727-33.

11. Goff MJ, Johnson RN, McDonald HR, Ai E, Jumper JM, Fu A. Intravitreal bevacizumab for previously treated choroidal neovascularization from agerelated macular degeneration. Retina. 2007;27(4):432-8.
12. Schouten JS, La Heij EC, Webers CA, Lundqvist IJ, Hendrikse F. A systematic review on the effect of bevacizumab in exudative age-related macular degeneration. Graefes Arch Clin Exp Ophthalmol. 2009;247(1):1-11. Review.

13. Bonnin P, Pournaras JC, Lazrak Z, Cohen SY, Legargasson JF, Gaudric A, et al. Ultrasound assessment of short-term ocular vascular effects of intravitreal injection of bevacizumab (Avastin) in neovascular age-related macular degeneration. Acta Ophthalmol. 2009 Jun 26. [Epub ahead of print]. [Internet]. 2009 [cited 2009 Jun 26]; 1-5. Avaliable from: http://www3.interscience. wiley.com/journal/122468038/abstract.

14. Gragoudas ES, Adamis AP, Cunningham ET Jr, Feinsod M, Guyer DR; VEGF Inhibition Study in Ocular Neovascularization Clinical Trial Group. Pegaptanib for neovascular age-related macular degeneration. N Engl J Med. 2004;351(27): 2805-16. Comment in: N Engl J Med. 2005;352(16):1720-1; author reply 1720-1. ACP J Club. 2005;143(1):18. N Engl J Med. 2004;351(27): 2863-5.

15. Rosenfeld PJ, Brown DM, Heier JS, Boyer DS, Kaiser PK, Chung CY, Kim RY; MARINA Study Group. Ranibizumab for neovascular age-related macular degeneration. N Engl J Med. 2006;355(14):1419-31.

16. Brown DM, Kaiser PK, Michels M, Soubrane G, Heier JS, Kim RY, Sy JP, Schneider S; ANCHOR Study Group. Ranibizumab versus verteporfin for neovascular age-related macular degeneration. N Engl J Med. 2006;355(14): 1432-44.

17. Rosenfeld PJ, Moshfeghi AA, Puliafito CA. Optical coherence tomography findings after an intravitreal injection of bevacizumab (avastin) for neovascular age-related macular degeneration. Ophthalmic Surg Lasers Imaging. 2005;36(4):331-5. Comment in: Ophthalmic Surg Lasers Imaging. 2005; 36(4):270-1.

18. Gunther JB, Altaweel MM. Bevacizumab (Avastin) for the treatment of ocular disease. Surv Ophthalmol. 2009;54(3):372-400. 